\title{
Strategy to Develop Reputation in Green Building in Indonesia
}

\author{
Taty Romauli (University of Pancasila) \\ Prof. Dr. Tri Widyastuti, SE, Ak, MM, CA (University of Pancasila) \\ Dr. Fahrudddin Salim, SE, MM (University of Pancasila)
}

\begin{abstract}
Previous studies had examined The Green Building in Indonesia, but none have discussed more thoroughly the relationship between competitive advantage, service quality, company performance, and implications for the company reputation. The purpose of this study is to get a clearer picture of how the Green Building's competitive advantage together with the excellent service quality provided by the Green Building can improve the performance, and the final result is how the company's reputation is formed. This research was conducted with quantitative techniques by involving 30 building managers of the Green Building in Jakarta. To analyze the relationship between variables, this study used Structural Equation Model approached with SmartPLS. The result of this research is the company's competitive advantage will have a small effect on the company performance, and company reputation if the service quality provided is not excellent.
\end{abstract}

Keywords:- Competitive Advantage, Service Quality, Company Performance, Company Reputation.

\section{INTRODUCTION}

This world populace getting more active to find the method to solve the pollution problem that getting worse every time. Excessive use of natural resources will affect the human environment. Environmental pollution will be increased and will cause damage to the environment. Irresponsible use of natural resources will lead to scarcity one day, which will harm human life. Many people agree that the Green Building concept is a good concept to preserve the environment for human life. The Green Building concept itself is environmentally friendly. By carrying out the concept of reuse, reduce and recycle, it is intended to increase human being awareness to preserve the environment. The benefits of applying the Green concept to buildings are: (1). Energy-saving consumption; (2). To reduce the amount of waste generated from daily activities; (3). Preserving natural resources for human survival; (4). Waste recycling, and waste minimization; (5). The healthier building occupied to increase human productivity. Because the use of energy becomes more efficient, the cost of electricity used will be lower, this is one of the direct benefits the Green Building users. Sick building syndrome is the management building that does not pay attention to good, and healthy air ventilation systems. This has been a problem in office buildings for several years. The Green building concept pays attention to use healthy ventilation systems and the use of non-toxic building materials. The healthy building will impact the healthier occupants, and the result is the occupants will be more productive at work because of the rooms fill with enough oxygen level. With the increasing level of human awareness of the benefits of the green concept in their daily lives, it is a good opportunity for building owners to build green buildings. The building's tenants will compete to find a building with healthy circumstances, and environmentally friendly to live or to work in. On the other hand, the Green Building owner expects a reward from the government when succeeds to preserve the environment by building an environmentally friendly building.

The Green Building in Indonesia began in 2011. The building concept has been designed from the beginning with an environmentally friendly concept and has to be audited to get a Green Building certificate. In building Green Building management, good building management is needed to manage all the equipment, and equipment in the building so that it still has a good performance in carrying out activities. The building management is needed to manage a Green Building appropriately. The building manager plays a very important role to run the Green Building operational system, and to provide superior services for the building's tenants. This process will cause a great impact on the building's performance. Building management with the Green Building concept is one way to maintain the Green certification that has been obtained.

The phenomenon of global warming and the scarcity of non-renewable energy, causes every scientific around the world try to innovate the renewable energies as an alternative (such as oil, and natural gas), and create environmentally friendly technology, it is called the green technology. Considering the largest energy use in the world is used in buildings (about 40\%), the energy-efficient management buildings are needed, in order to reduce the energy consumption.

Jakarta as the capital city of Indonesia with an area of about $650 \mathrm{~km} 2$ is getting denser from year to year. Based on data from BPS Jakarta, the total population of Jakarta in 2010 was 9,607 million. In 2018 the population increased to 10,467 million or increased by 859,840 people. Population growth, growth in the construction of tall buildings, if we do not manage the environmental sustainability carefully, will allow environmental degradation. 
A significant difference in buildings with a design or that has been certified Green Building is that a certified building will cost more upfront but will provide savings from building maintenance costs. This occurs because the building prioritizes efficiency in energy, water, and materials so that the costs incurred per month will be cheaper.

The implementation of the green building concept in Indonesia has not gone as expected. In general, building regulations in Indonesia are regulated in Law No. 28 of 2002 concerning Buildings (Law 28/2002), and also in Government Regulation No. 36 of 2005 (PP 36/2005) concern about implementing regulations of Law 28/2002 concerning Buildings. Buildings, but in early 2015 a Regulation of the Minister of Public Works and Public Housing of the Republic of Indonesia No. 02/PRT/M/2015 of Green Buildings was issued.

Indonesia currently has an institution that deals with the "Green Building Council Indonesia" (GBCI). GBCI is an independent (non-government), and a non-profit institution that is fully committed to public education in applying environmental best practices, and facilitating the sustainable transformation of the global building industry. One of the GBCI programs is to organize green building certification activities in Indonesia based on a unique Indonesian assessment tool called Greenship, which is the assessment system used as a tool for industrial players, buildings, both entrepreneurs, architects, mechanical electrical technicians, and interior designers. GBCI also prepares the best practices and achieving standards. Greenship has implementation guides for Neighborhoods, Homes, New Buildings, Existing Buildings, and Interior Space with different criteria and points.

In addition to the GBCI institution, several buildings in Indonesia are Green Building certified provided by the Building and Construction Authority which is a Singapore government-owned institution that provides an assessment of the Green Building in Singapore known as GreenMark. Until now, 9 recorded buildings in Indonesia have been certified as Green Building by the Singapore Building and Construction Authority from 2011 to 2019.

The Green Building Certification is valid for 3 years after the certification is awarded. From a total of 34 buildings that have received this certification, GBCI, and BCA have registered only 3 buildings that re-certify after the previous certification validity period has expired. Only about $9 \%$ of certified buildings are willing, and able to certify. This becomes a question of how the building management procedures in maintaining the company's reputation.

In the application of Green Building in a building that is always a concern is how to achieve energy efficiency in electricity, water, material or material efficiency, environmental quality improvement, waste reduction, and most important is optimization in daily cost. This sustainability can only be achieved by carrying out an operation and optimizing the maintenance of the building. The sustainability of a Green Building does not stop when the building is certified with green building. The operation and maintenance process carried out by the building manager plays an important role in maintaining the sustainability of the Green Building.

According to the Regulation of the Minister of Public Works No. 24/PRT/M/2008 is concerning the guidelines for maintenance, and to care of buildings. Building maintenance is the activity of maintaining the reliability of the building, and its infrastructure and facilities so that the building is always functioning properly (preventive maintenance). Meanwhile, to take care building is the activity of repairing, and/or replacing parts of the building, components, building materials, and facilities, and infrastructure so that the building remains functional (curative maintenance). Maintenance of buildings can be in the form of rehabilitation, renovation, and restoration activities.

Building maintenance activities have not been carried out optimally because of the assumption that building activities are more important than maintenance activities. In general, a measure of the success of development in an area tends to be the number of new buildings. This causes maintenance activities for existing buildings not prioritized, meaning that they have not received an adequate budget. Management in building maintenance sometimes is not well organized.

The reliability of the building, especially the Green Building, is an absolute requirement that must be met. Therefore, it is necessary to increase attention in terms of maintenance of buildings following the Green Building concept design. Standards related to building maintenance activities are required to achieve optimal maintenance results, including planning, organization, scheduling, implementation, and control in the concept of reuse, reduce, and recycle. Building managers need to carry out good maintenance activities to maintain the condition of the building, and all its components so that it is always functional.

Performance appraisal or business performance must be measured to be used as a basis for decision making both internal, and external. According to Helfert (1996:67) states that "Company performance is the result of many individual decisions made continuously by management." Performance is also used as a measure of how efficient, and effective an organization or a manager is to achieve adequate goals (Stoner et. Al, 1996).

Every company must have a competitive advantage because the company's performance arises from the achievement of competitive advantage (Gyampah \& Acquaah, 2007:575). Competitive advantage depends more on valuable, rare, and difficult to imitate resources owned by the organization itself (Stiles \& Kulvisaechana, 2003). 
The competitive advantage of a company must be balanced with good service performance as well. The phenomenon that occurs is the competitive advantage that the company has without good service provided by the company to customers will be a minus value for customers. Companies must pay attention to maintain delivering good service quality, customer complaints in managing their business properly. This will form the customer's trust in the company.

Thus, service performance and trust can better answer the problems that arise in determining service quality because after the services received the consumers will be able to judge the quality they received from the company. Several service points that must be of concern to the building manager include tangible qualities that can be felt directly by building tenants such as cleanliness, tidiness, and comfortable with cool air, and suitable lighting. In daily life, building tenants expect to have a comfortable place to work, and convenience communication, and easy for getting information from the building manager. Every complaint given by tenants is expected to be a quick response and addressed by the building manager. As a building with Green Building certification, tenants also expect building managers to carry out operations, and maintenance with the Green Building concept that emphasizes reuse, reduce, and recycle.

If the results given do not match the customer's expectations, it is suspected that dissatisfaction occurred. The impact of this is the company's reputation becomes negative. A negative reputation attached to a product/service has a negative impact on building customers, and vice versa if a positive reputation is attached to a product/service it will have a positive influence from the customers.

The effect of quality on reputation, Aryska's research (2017) proves an influence between company reputation and service quality. Likewise, research conducted by Wulandari, and Rasipan (2017), Duygun e.t.al (2014) show that there is a significant relationship between service quality and company reputation. Furthermore, Kurniasari and Ernawati (2012) stated that trust is important for all companies because companies cannot build relationships without trust. Also, trust is very important for service providers because it promises customers a product or service that cannot be seen, for which the customer must pay before experiencing the product or service. Trust can be used as a basis for customers in determining the renting of the building to be chosen.

\section{LITERATURE REVIEW}

Competitive advantage is a management concept that is so popular in contemporary management literature today. This is partly due to the rapid changes facing companies today, the complexity of the business environment, the impact of globalization, and unstructured markets, changing customer needs, competition, the information, and communication technology revolution, and world free trade
(Al-Rousan \& Qawasmeh, 2009). Competitive advantage as an organizational capability in recording performance that is difficult to imitate by its competitors for now and in the future (Kotler, 2000). In view that the competitive advantage that grows from company value can create value for buyers that exceeds the cost to create it. Value is what buyers are willing to pay, and superior value arises from bidding at a lower price than a competitor for the same benefits, or offering a unique benefit that is more than sufficient to compensate for the higher price.

Albakri (2008) emphasized that competitive advantage is the ability of an organization to attract customers, and build prestige for the organization or its products, and increase the perceived value of customers, and satisfy them, which also includes the ability to provide various values to customers.

One of the dimensions of competitive advantage according to Moghli, Abdallah, \& Muala (2012) is time or period. The time it takes for a company to present its products to customers; quality; cost; and flexibility or the company's ability to respond for the change. Meanwhile, according to Diab (2014), the competitive dimensions consist of cost, flexibility, delivery, and quality. Meanwhile, according to Mehrmanesh, Zafargh, Andi \& Managhebi (2014) used the dimensions of competitive advantage of cost, quality, and other dimensions are general image, design, price, support, and differentiation. When examined from the three studies, it appears that the similarities for the dimensions of measuring competitive advantage are always talking about quality, price, and delivery method.

The competitive advantage must be continuously updated so that the company's bargaining value can be sustainable, this is what is commonly known as the Sustainable Competition Advantage (SCA). Vinayan, Jayashree \& Marthandan (2012) stated that there are four dimensions of SCA, which are: (1). Effective supply chain management, (2). Product differentiation and innovation, (3). Organizational responsiveness, and (4). Cost leadership. Furthermore, another opinion regarding the dimensions of competitive advantage is conveyed by Izadi (2013), who also states four dimensions of competitive advantage: (1). Quality, (2). Efficiency, (3). Innovation, and (4). Responding to customers. It can be seen from several previous studies that there are different dimensions for competitive advantage, all depending on the type of company, and the need for research. According to Emad Aki Kasasbeh (2017), take the dimensions of competitive advantage of innovation, sustainable product and service development, service quality, customer response, strategic assets, market differentiation, education, and training and system integration. The dimensions of competitive advantage can also be expressed by offering attractive prices, material quality, product and product differentiation based on market tastes. When examined from the six studies, it appears that the equation for the dimensions of measuring competitive advantage is always talking about quality and price. 
Quality is a dynamic condition related to products, services, people, process, and environments that meet expectations (Goetsch and Davis, in Fandy Tjiptono, 2008:51). According to Gronos (Atik Septi Winarsih and Ratminto, 2008), service is an activity or a series of invisible (intangible) activities that occur as a result of interactions between consumers, and employees or things provided by service providers intended to solve consumer/customer problems. According to Freddy Rangkuti (2009), the level of service quality cannot be assessed from the company's adjective but must be viewed from the customer assessment. Therefore, in formulating service strategies and programs, companies must be oriented towards the interests of customers by paying attention to the components of service quality.

According to Tjiptono (Aditya, 2011:23), service quality is something that is perceived by customers. Customers will evaluate the perceived quality of a service based on what they describe in their minds. Customers will turn to other service providers who are better able to understand customer-specific needs and provide good service.

Customer perceptions of service quality can be measured, and evaluated through the dimensions of service quality as stated by Zeithaml, Parasuraman, and Berry (2009, p26) as follows:

$>$ Tangibles (physical appearance), including physical facilities, employee appearance, equipment used, and physical presentation.

$>$ Reliability (trustworthiness), which is the ability to provide promised services that are reliable, and precisely.

$>$ Responsiveness (responsiveness) is the readiness of employees to provide services, and to help consumers

$>$ Assurance (guarantee), including knowledge, courtesy, and the ability of employees to gain customer trust.

$>$ Empathy (caring) is the company's concern for consumers.

Company performance is a complete display of the state of the company for a certain period time, is a result or achievement that is influenced by the company's operational activities in utilizing its resources (Helfert, 1996 in Cecilia Srimindarti, Fokus Ekonomi, 2004: 53). Measuring company performance is very important for management to evaluate company performance, and to plan future goals. Various information is gathered so that the work performed can be controlled and accounted for. In order to achieve efficiency and effectiveness throughout the company's business processes. An overview which is a measure of company performance can be obtained from two sources, which is financial information and nonfinancial information.

Owen et al. (2001) argue that sustainable company performance growth is performance growth in the long run as a result of the company's ability to maintain its ability to produce products and services with high quality. Meanwhile, company performance is measured based on a set of selected indicators that can make comparisons between one company and another (Ketokivi \& Schroeder, 2004).

Meanwhile, Cho \& Pucik (2005) stated that sustainable business performance is one way to satisfy investors, and can be represented by profitability, growth, and market value, all aspects complement one another. This opinion explains the many things that must be achieved in finding sustainable business performance. Customer and employee satisfaction are also two aspects that need to be considered. Customers want companies to provide goods and services that meet their expectations. To be able to do that, companies must understand their customers' needs, avoid defects, increase the perceived quality, and added value in their offerings.

The company's performance should be a measurable result and describe the empirical conditions of a company of various sizes. Sri Widyanesti and Siti Masyithah (2018) in their research convey the dimensions used in company performance are financial performance and non-financial performance. According to Morgan et al., (2009), indicators that can be used to measure firm performance are market effectiveness and profitability.

Santos \& Brito (2012), convey several dimensions of sustainable business performance as follows: (1). Financial Performance (Profitability, Growth, Market Value), (2). Strategic Performance (Customer Satisfaction, Employee Satisfaction, Environmental Performance, Social Performance). The dimensions divided into 2 things, they are financial and strategic which are evaluated. The same thing was also found in Girish Nair's (2016) study using the dimensions of financial performance, non-financial performance, and operational performance.

Murugesan Selvam, Jayapal Gayathri, Vinayagamoorthi Vasanth, Kasilingam Lingaraja \& Sigo Marxiaoli, stated in their research that the dimensions used in measuring company performance are profitability performance, market value performance, growth performance, employee satisfaction, customer satisfaction, environmental performance, environmental audit performance, corporate governance performance, and social performance.

Regarding company reputation, Bromley (2002), and Sandberg (2002) argue that reputation is a consensus and socially perceived impression of how a company will behave in any situation. This opinion initiates that reputation is important to improve the company's social performance on the impression and consensus that felt by the surrounding environment. Reputation is very important because it will apply to any situation. Company reputation is also believed to be able to drive business success, as stated by Bennett \& Kottasz (2003). Where it is conveyed that the definition of a reputation as an image, and identity that develops over a longer time, both in terms of consistency, reliability, and credibility. This opinion 
focuses on the company's reputation in the long term in terms of consistency, reliability, and company credibility.

The opinion of Bennett \& Kottasz (2003) is in line with the opinion of Marken (2004), which states that the company's reputation as quality products, and services, innovative capabilities, long-term investment plans, retaining talent, and quality management control. The study of this opinion states that reputation is built on daily, and long-term activities. Based on some of the opinions above, it can be seen that the company's reputation is built for the long-term company so that the activities or activities of the company every day must have quality.

According to Melo, Garrido-Morgado, and OlmedoCifuentes et al, reputation is a collective perception related to the attributes, image, and corporate identity. Baldarelli, and Gigli, and Roberts, and Dowling observe that a good reputation is an asset that enables a company to achieve sustainable profitability, and performance. According to Soviadi Nor Rachman (2006), the dimensions of a company's reputation can be seen from its competence, credibility, and good name. in the research of Dolores Gallardo-Vázquez, Luis Enrique Valdez-Juárez, and Ángela María Castuera-Díaz, the dimensions of reputation used are: (1). Employee motivation, satisfaction, and loyalty, (2). The firm's transparency, and good governance, (3). Customer satisfaction, and loyalty, and (4). Our products, and services' added value. Belén Ruiz, Águeda Esteban, and Santiago Gutiérrez (2014), in the research they are using the dimensions for the reputation variables, they are: offer, customer care, innovation, employer branding, integrity, leadership, reliability, and financial strength, social section, satisfaction, and trust.

Based on the literature review and a review of previous research, the theoretical framework of this research can be described to answer research problems:

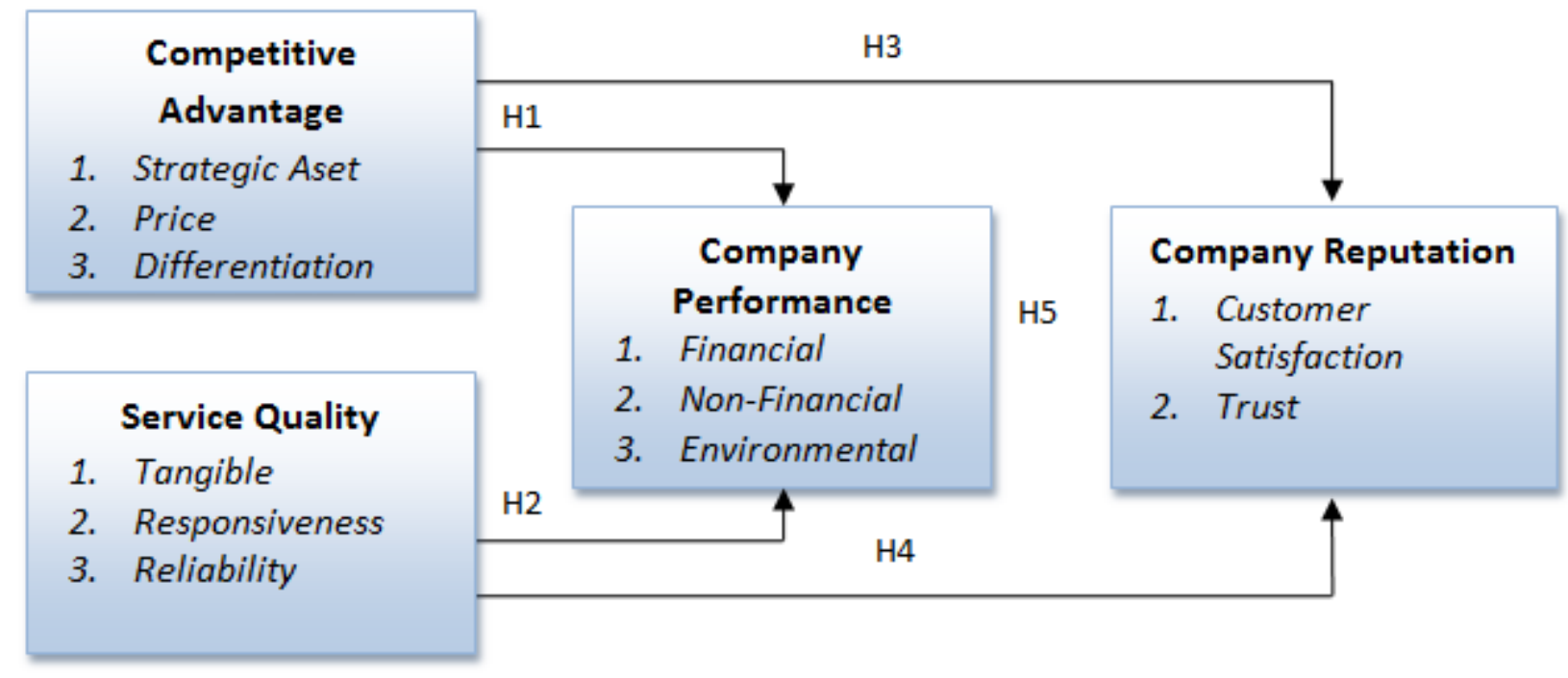

Fig 1:- Research Framework

The type of research used is descriptive, which is research conducted to obtain a position about the research variables and verification research which is a research to determine the influence between variables through a hypothesis. This study focuses on the strategic management field, and specifically discusses the variables of competitive advantage, and service quality, their effects on company performance, and their implications for the company reputation. With the objectives and benefits of this study, the design of this study uses a quantitative type that aims to analyze the relationship between one variable, and another (causality) through hypothesis testing. This study uses data, and information sources, and primary data using a questionnaire. The target population is building managers at the Green Building Management company in Jakarta.

In this quantitative analysis using two types of analysis, descriptive analysis and verificative analysis. Descriptive analysis is related to qualitative research variables to seek information obtained from the research results. In analyzing the relationship between research variables, the measurement used the SEM approach (structural equation sdgvmodel), and the SmartPLS processing software.

\section{RESULT AND DISCUSSION}

In Structural Equation Modeling, there are two types of models that are formed, they are the measurement model (outer model), and the structural model (inner model). The measurement model describes the proportion of the variance of each manifest variable (indicator) that can be explained in the latent variable. Through the measurement model, it will be known which indicators are dominant in the formation of latent variables. After the measurement model for each latent variable is described, a structural model will be described which will examine the effect of each exogenous latent variable on the endogenous latent variable. 
The results of the calculation of the entire model using SmartPLS 2.0 are as follows:

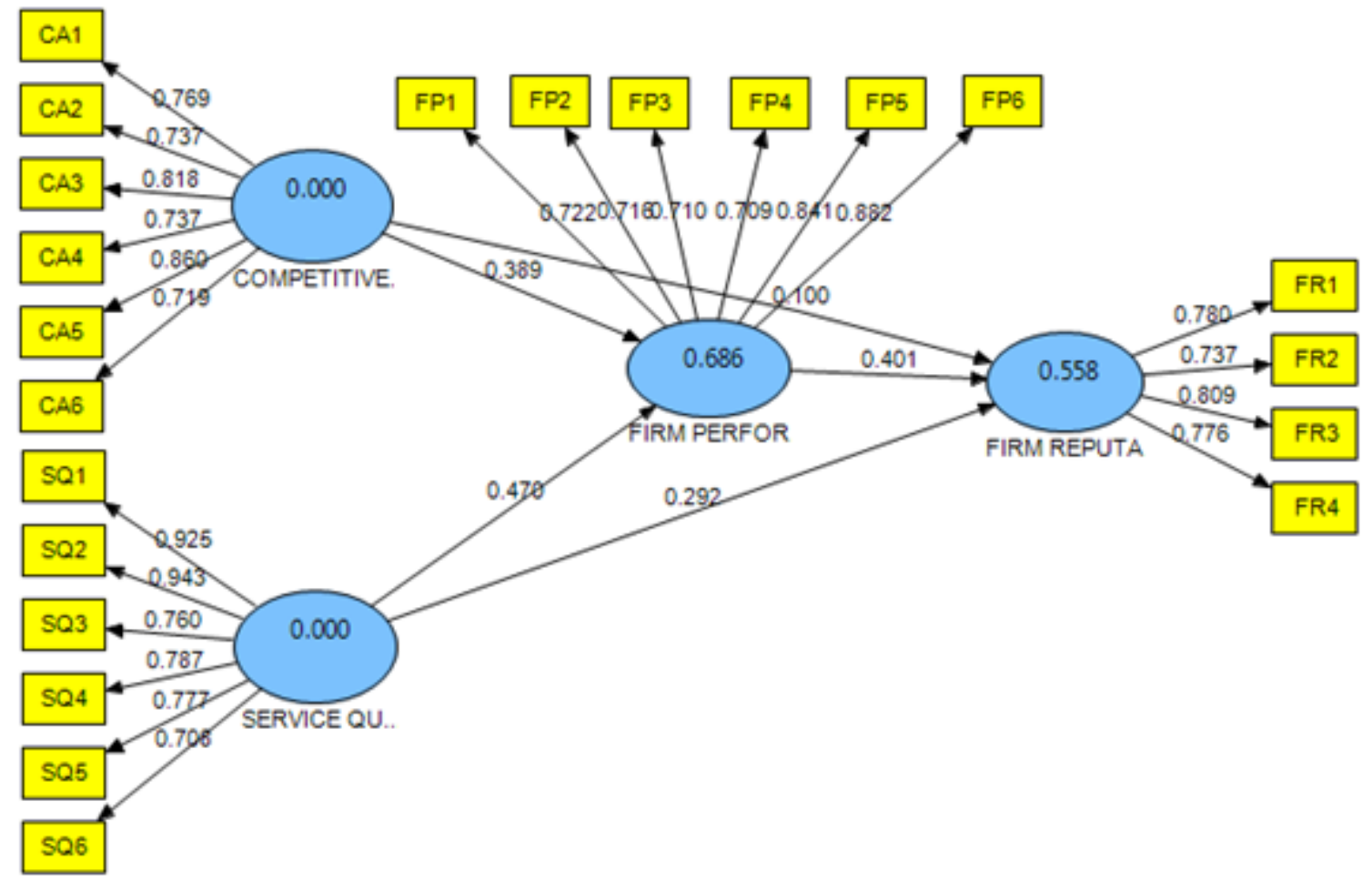

Fig 2:- Model Path Diagram

The results of the structural equation modelling with the PLS approach is carried out by looking at the results of the measurement model (outer model), and the results of the structural model (inner model). The loading factor value of all manifest variables has a positive relationship to the latent variables for each manifest variable greater than 0.7 so it can be said to be quite high. These results indicate that the use of the six manifest variables is stated to be able to measure latent variables accurately. The four latent variables have AVE and communality values that are greater than the specified value, which is 0.5 , so that all manifest variables regarding competitive advantage, service quality, company performance, and company reputation met the requirements of convergent validity.

\begin{tabular}{|c|c|c|c|}
\hline Variable & Composite Reliability & Cronbachs Alpha & Remarks \\
\hline Competitive advantage & 0.900 & 0.867 & Reliable \\
\hline Company performance & 0.895 & 0.862 & Reliable \\
\hline Company reputation & 0.858 & 0.779 & Reliable \\
\hline Service quality & 0.925 & Reliable \\
\hline
\end{tabular}

Table 1:- The Results of Composite Reliability

Source: Data processed using software PLS

The result is the composite reliability value produced by all constructs is very good, which are all above 0.7 , and can be concluded that all construct indicators are reliable or in other words, all manifest variables of the four latent variables are proven to have accuracy, consistency, and accuracy of instruments in a measure the construct well.

\section{Hypothesis Testing Analysis}

Hypothesis testing is done by looking at the t-statistic as measured by the t-table. Hypothesis testing in PLS is carried out by using the bootstrapping method of the sample.The results of the calculation of the entire model using SmartPLS 2.0 are as follows: 


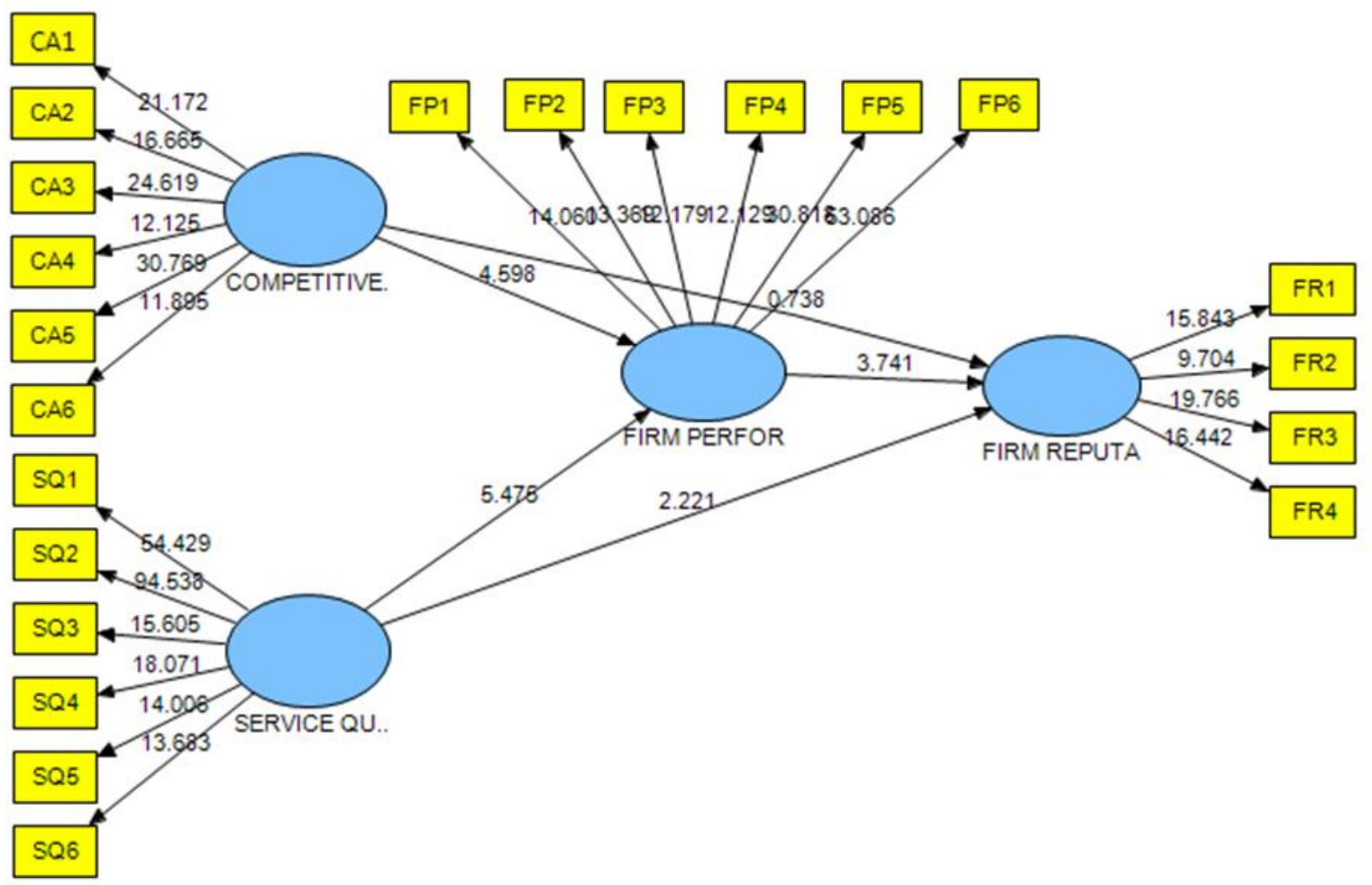

Fig 3:- T-Values Diagram

The effect between competitive advantage and company performance

$1{ }^{\text {st }}$ Hypothesis:

$\mathbf{H}_{\mathrm{a}}$ : Competitive advantage has a significant effect on company performance

\begin{tabular}{|c|c|c|c|c|c|}
\hline Construct Relations & $\begin{array}{c}\text { Path } \\
\text { Coefficient }\end{array}$ & $\begin{array}{c}\text { T Statistics } \\
(\mid \text { O/STERR|) }\end{array}$ & $\begin{array}{c}\text { T- } \\
\text { table }\end{array}$ & Remarks & $\begin{array}{c}\text { Conclusio } \\
\mathbf{n}\end{array}$ \\
\hline $\begin{array}{c}\text { Competitive advantage -> Company } \\
\text { performance }\end{array}$ & 0.389 & 4.598 & 1.96 & $\begin{array}{c}\mathrm{H}_{0} \\
\text { rejected }\end{array}$ & Significant \\
\hline
\end{tabular}

Table 2:- Test "t" Competitive advantage on Company Performance

Source: Primary Data Processed by Author, 2020

Based on the statistical parameter, it shows that $\mathrm{t}_{\text {count }}$ of 4,598 greater than $t_{\text {table }}$ of 1,96 at $5 \%$. Significant level. This means that competitive advantage has a significant effect on company performance. Thus, $\mathrm{H}_{\mathrm{a}}$ was accepted and $\mathrm{H}_{\mathrm{o}}$ was rejected.

The competitive advantage of a company is need to improve and maintain the company's performance. It is also known that competitive advantages can be achieved through cooperation with the company's human capital. The research results prove that competitive advantage has a significant effect on company performance. The better the competitive advantage means the better the company's performance will be.

The dimensions of the strategic building location with the ease of reaching the building location are one of the supports of attracting building tenants to choose the building to rent. With the need for humans who want to be fast, and practical, it turns out that the need for complete facilities in the building area, and also the availability of adequate parking space is also a reference for building tenants in choosing a location. All of these dimensions are also supported by the provision of building rental prices, and service charge prices which have competitive prices, which will be a positive added value in attracting building tenants. High tenant occupancy rates in the building will increase the building's income.

The results of this study support previous findings by Elijah and Millicent (2018), which prove that the company's competitive advantage will drive company performance. Likewise, the research of Wijayanto et al (2019), proves that the competitive advantage possessed by the company will encourage company performance. Arbawa and Wardoyo (2017) also state that the company's competitive advantage will drive performance. Kaleka \& Morgan (2017) in their research prove that competitive advantage and services owned by the company will drive company performance. Talaja and Ercegovic (2013), state that a company's competitive advantage can improve company performance. Sihite (2018), in a theoretical research study, discusses the positive relationship of competitive advantage on long-term or sustainable performance. 
$>$ The Effect of service quality on Company Performance

$2^{\text {nd }}$ Hypothesis:

$\mathbf{H}_{\mathbf{a}}$ : Service quality has a significant effect on company performance

\begin{tabular}{|c|c|c|c|c|c|}
\hline Construct Relations & $\begin{array}{c}\text { Path } \\
\text { Coefficient }\end{array}$ & $\begin{array}{c}\text { T Statistics } \\
(\mid \text { O/STERR|) }\end{array}$ & $\begin{array}{c}\text { T- } \\
\text { table }\end{array}$ & Remarks & $\begin{array}{c}\text { Conclusio } \\
\mathbf{n}\end{array}$ \\
\hline $\begin{array}{c}\text { Quality of Service -> Company } \\
\text { Performance }\end{array}$ & 0.470 & 5.475 & 1.96 & $\begin{array}{c}\mathrm{H}_{0} \\
\text { rejected }\end{array}$ & Significant \\
\hline
\end{tabular}

Table 3:- Test “t” Quality of Service to the Company's Performance

Source: Primary Data Processed by Author, 2020

Based on statistical parameters, it shows that $\mathrm{t}_{\text {count }}$ of 5.475 is greater than $t_{\text {table }}$ of 1.96 at the $5 \%$ significance level. This means that service quality has a significant effect on company performance. Thus, Ha was accepted and Ho was rejected.

Service quality encourages customers committed to consume the company's products and services served. It has an impact on the increased on the market share. Quality of service is very important in retaining customers for a longer time. Companies that have superior services will be able to maximize the company's financial performance.

The level of service quality cannot be assessed from the company's point of view but must be viewed from the customer's point of view. Therefore, in formulating service strategies, and programs, companies must be oriented towards the interests of customers by paying attention to the components of service quality.

The results of the study prove that service quality has a significant effect on company performance. The better the quality of service, the better the company's performance will be. These results indicate that there is a positive, and strong enough relationship between service quality and company performance.

In the term of choosing building to rent, prospective tenants will consider the internal conditions, and the outer area of the building, whether it is clean, and whether it is comfortable to live in. By doing activities in a clean, and comfortable environment, it is hoped that humans will be productive. Tenants also expect good communication between tenants and building managers. Providing clear, and precise information will greatly assist in enhancing good communication between the two parties. As a building that has been certified as a Green building, the building tenants hope that the manager will manage the building based on the standard operating procedure in accordance with the provisions of green buildings. All of these things become the dimensions studied are part of the quality of service provided to the tenants. When all these things can be fulfilled by the building manager, it will increase the satisfaction of the building tenants.

The results of this study are in accordance with previous findings by Kaleka and Morgan (2017) which prove that the services owned by the company will drive company performance. Likewise, research by Hadi et al (2018) proves that the quality of services owned by companies will encourage company performance. Latif and Baloch's research (2015) also proves that the quality of services owned by companies will drive company performance. Cheng and Lin (2014) state that the quality of services owned by the company will encourage company performance.

The effect of Competitive Advantage on the Company's Reputation

$3^{\text {rd }}$ Hypothesis:

$\mathbf{H}_{\mathrm{a}}$ : Competitive advantage has a significant effect on the company's reputation

\begin{tabular}{|c|c|c|c|c|c|}
\hline Construct Relations & $\begin{array}{c}\text { Path } \\
\text { Coefficient }\end{array}$ & $\begin{array}{c}\text { T Statistics } \\
(\mid \mathbf{O} / \text { STERR|) }\end{array}$ & $\begin{array}{c}\text { T- } \\
\text { table }\end{array}$ & Remarks & Conclusion \\
\hline $\begin{array}{c}\text { Competitive advantage -> Company } \\
\text { Reputation }\end{array}$ & 0.100 & 0.738 & 1.96 & $\begin{array}{c}\mathrm{H}_{0} \\
\text { accepted }\end{array}$ & $\begin{array}{c}\text { Not } \\
\text { Significant }\end{array}$ \\
\hline
\end{tabular}

Table 4:- Test t Competitive Advantage to Company Reputation Source: Primary Data Processed by Author, 2020

Based on statistical parameters, it shows that $t_{\text {count }}$ of 0.738 is smaller than $t_{\text {table }}$ of 1.96 at a significance level of $5 \%$. This means that competitive advantage does not have a significant effect on the company's reputation. Thus $\mathrm{H}_{\mathrm{a}}$ was rejected and $\mathrm{H}_{\mathrm{o}}$ was accepted.

Competitive advantage according to Resources-based View, does not depend on natural resources, technology or economies of scale as long as it is easily imitated by competitors. Competitive advantage depends more on valuable, rare, and difficult to imitate resources owned by the organization itself. Therefore, it is important to take into account the aspects of Human Resource Management in the company's strategy, especially in the context of the human capital (the collection of employee capabilities).

The results of this study prove that competitive advantage does not have a significant effect on company reputation. This is because the relationship between competitive advantage and company reputation is very low. The occurrence of this very low relationship indicates that the competitive advantage built by the company has not 
been able to improve its reputation as a competitive building manager. The results of this study are different from previous findings by Gallardo et.al (2019) which state that competitive advantage has an impact on business performance and company reputation.

The phenomenon that occurs is the competitive advantage that the company has without good service provided by the company to customers will be a minus value for customers. Companies must be able to pay attention to maintaining service quality, customer complaints in managing their business properly. This will form customer trust in the company.

The results of the structural equation show that competitive advantage has a very low effect on the company's reputation. This is possible because generally, the relationship that occurs is the company's reputation which affects the company's performance. In previous research, the relationship between the two variables was positively correlated. In early research by Roberts, P.W. \& Dowling,G. R. (2002), which discussed the field of corporate finance, there is a correlation between company reputation, and performance. Furthermore, in the research of Boyd, B. K., Bergh, D.D, \& Ketchen, D. J. (2010), which states that in theory, the relationship of reputation and performance has a good closeness. Finally, from Lourenço, I. C, Callen, J. L., Branco, M. C., \& Curto, J. D. (2014), which emphasizes that in gaining reputation, it is necessary to control external factors and reputation as resource intangibles can affect the sustainability of the company or sustainable performance. From this, it can also be concluded that there may be a reciprocal relationship between reputation, and performance.

The effect on Service Quality on Company's Reputation $4^{\text {th }}$ Hypothesis:

$\mathbf{H}_{\mathbf{a}}$ : Service quality has a significant effect on the company's reputation

\begin{tabular}{|c|c|c|c|c|c|}
\hline Construct Relations & Path Coefficient & T Statistics (|O/STERR|) & T-table & Remarks & Conclusion \\
\hline Quality of Service -> Company Reputation & 0.292 & 2.221 & 1.96 & $\mathrm{H}_{0}$ rejected & Significant \\
\hline
\end{tabular}

Table 5:- Test t Quality of Service to the Company's Reputation Source: Primary Data Processed by Author, 2020

Based on statistical parameters, it shows that $t_{\text {count }}$ of 2.221 is greater than $t_{\text {table }}$ of 1.96 at a significance level of $5 \%$. This means that service quality has a significant effect on the company's reputation. Thus, $\mathrm{H}_{\mathrm{a}}$ was accepted and $\mathrm{H}_{\mathrm{o}}$ was rejected.

Quality of service is very important in retaining customers for a longer time. Companies that have superior services will be able to maximize the company's financial performance. To maintain and to take care activities in buildings must be increased along with the rapid development in Jakarta.

The results of this study prove that service quality has a significant effect on company reputation. The better the quality of service, the better the company's reputation will be. These results indicate that there is a positive and strong enough relationship between service quality and company reputation.

These findings support previous research by Torres et.al (2013) which states that service quality outcomes have an impact on dimensions on reputation. Likewise, research by Mutle and Shonhe (2017) which proves that the results of the dimensions of service quality have an impact on reputation. Esmaeilpour et.al (2017) research also states that service quality has an impact on reputation.

In public buildings, building reliability is an absolute requirement that must be met. Therefore, it is necessary to increase attention in terms of maintenance of existing buildings. Required standards relating to building maintenance activities to achieve optimal maintenance results, including planning, organization, scheduling, implementation, and control. Building managers need to carry out good maintenance activities to maintain the condition of the building, and all its components so that it is always functional.

The effect of Company Performance on Company
Reputation
5ft Hypothesis:
$\mathbf{H}_{\mathrm{a}}$ : Company performance has a significant effect on
the company's reputation

\begin{tabular}{|c|c|c|c|c|c|}
\hline Construct Relations & Path Coefficient & T Statistics (|O/STERR|) & T-table & Remarks & Conclusion \\
\hline
\end{tabular}

Table 6:- Test t Company Performance on Company's Reputation Source: Primary Data Processed by Author, 2020

Based on statistical parameters, it shows that $t_{\text {count }}$ of 3,741 is greater than $t_{\text {table }}$ of 1.96 at the $5 \%$ significance level. This means that company performance has a significant effect on company reputation. Thus, $\mathrm{H}_{\mathrm{a}}$ was accepted and $\mathrm{H}_{\mathrm{o}}$ was rejected. 
Reputation is the consensus, and socially felt the impression of how the company will behave in any situation. reputation is important to improve the company's social performance on the impression, and consensus felt by the surrounding environment. Reputation is very important because it will apply to any situation. The company's reputation is also believed to be able to drive business success.

The results of this study prove that company performance has a significant effect on company reputation. The better the company's performance, the impact on the company's reputation will increase. These results indicate that there is a positive, and strong enough relationship between company performance and company reputation.

This finding is with previous research by Gallardo et.al (2019) in their research that stated that business performance has an impact on company reputation.

Success in achieving company goals is management achievement. Performance appraisal or business performance must be measured to be used as a basis for decision making both internal and external. A company with a good performance in managing a building will directly increase its reputation in the eyes of consumers. If the results given to the tenants of the building do not match expectations, it is suspected that dissatisfaction will occur. The impact of this is the company's reputation becomes negative. A negative reputation attached to a product or service has a negative impact on building tenants, and vice versa if a positive reputation is attached to a product/service it will have a positive influence on the tenant.

\section{CONCLUSION, LIMITATIONS AND SUGGESTIONS}

\section{Conclusion}

The aim of this research is to analyze the effect of competitive advantage, and service quality on company performance, and its implications for the company's reputation. The results of hypothesis testing using SEM SMART PLS analysis with 2 independent variables, competitive advantage and service quality, and one dependent variable, company reputation with one mediating variable, company performance, shows that:

- Competitive advantage has a positive effect on company performance. The higher the competitive advantage of the Green Building Management Company in Jakarta, the higher the company's performance will be. The competitive advantage possessed by the company can improve the performance of the company.

- Service quality has a positive effect on company performance. The higher the quality of services provided by the Green Building Management Company in Jakarta, the higher the company's performance will be. The high quality of service has an impact on increasing the performance of the company.
- Competitive advantage does not have a major effect on the company's reputation. The competitive advantage possessed by the Green Building Management Company in Jakarta has not been able to rapidly improve the company's reputation.

- Service quality has a positive effect on the company's reputation. The higher the quality of services provided by the Green Building Management Company in Jakarta, the higher the company's reputation will be. The high quality of service has an impact on increasing the company's reputation in the eyes of its consumers.

- Company performance has a positive effect on company reputation. The higher the company perSformance owned by the Green Building Management Company in Jakarta, the higher the company's reputation will be.

\section{Research Limitation}

This study has limitations in terms of:

- The number of respondents in this study is still very limited (30 respondents) from a total of 34 buildings with Green Building certification. Four of the buildings were not willing to fill out the questionnaire.

- Some respondents were not careful in reading the questionnaire which made it possible for the respondent to not take the questionnaire seriously so that some answers were found to be inconsistent.

\section{Suggestion}

The next research is expected to be able to present higher quality research results with some input regarding several things including:

- The researcher then adds the measurement of competitive advantage with other dimensions because the results of the measurement of competitive advantage by using the dimensions of strategic location, price, and differentiation do not produce a bigger effect on the company's reputation.

- With time, the development of technological innovation will always develop, and more energy-saving and environmentally friendly products will be created. Building managers are expected to follow the technology developments with increasingly sophisticated energy-saving innovations.

- Based on the results of data processing, there is a competitive advantage, the quality of service together with company performance has an effect of $55.8 \%$ on the formation of the company's reputation. The value of $44.2 \%$ is the contribution of other variables that affect reputation. According to the author's observations, other variables that can be used to examine reputationforming factors include product quality, organizational commitment, CSR, ethics, and good corporate governance. According to Budi Hermawan (2011), good, and reliable product quality will enhance the company's reputation. Customer satisfaction will be achieved when the product purchased provides good quality value. CSR activities carried out by companies as part of corporate philanthropic activities affect the company's reputation. The community will give positive values to companies that carry out CSR activities. This 
can be proven by research conducted by Vázquez, Luis Enrique Valdez-Juárez and Ángela María Castuera-Díaz (2019). In their research, it was found that CSR activities will increase the company's reputation.

- The government's participation in providing full support in the development of Green Building in Indonesia is needed. Providing rewards or incentives for buildings that design their buildings with a green concept can be the right booster. This incentive can be in the form of a tax deduction for these buildings. This will increase the desire of building owners to build a Green Building.

\section{REFERENCES}

[1]. Hair et al. (2010). Multivariate Data Analysis. Seventh Edition. Pearson Prentice Hall.

[2]. Latan, Hengky. (2012). Structural Equation Modeling : Konsep dan Aplikasi Menggunakan Program LISREL 8.80. B, andung : Alfabeta.

[3]. Lupiyoadi, Rambat, A. Hamdani. (2008). Manajemen Pemasaran Jasa. Cetakan Keempat. Jakarta: Salemba Empat.

[4]. Malhotra, K Naresh. (2010). Marketing Research. 6th Edition., Prentice Hall, Inc.

[5]. Tjiptono, F, andy dan Ch, andra, Gregorius. (2011). Service, Quality, dan Satisfaction Edisi 3. Yogyakarta: Penerbit, andi.

[6]. Tom Woolley, Sam Kimmins, Paul Harrison \& Rob Harrison, (1997). Green Building Handbook, Volume 1.

[7]. Anita Talaja dan Josipa Ercegović (2013). Competitive advantage and the company's performance: exploring the differences and relationship.Proceedings in ARSA-Advanced Research in Scientific Areas.

[8]. Anna Kaleka and Neil A. Morgan, (2017). Which Competitive Advantage(s)? Competitive AdvantageMarket Performance Relationships in International Markets.

[9]. Asante Boakye Elijah and Adu-Damoah Millicent, (2018). The Impact of A Sustainable Competitive Advantage On A Firm's Performance: Empirical Evidence From Coca-Cola Ghana Limited.

[10]. Dolores Gallardo-Vázquez, Luis Enrique ValdezJuárez \& Ángela María Castuera-Díaz (2019). Corporate Social Responsibility as an Antecedent of Innovation, Reputation, Performance, , and Competitive Success: A Multiple Mediation Analysis.

[11]. Eduardo Torres-Moraga, Cristóbal Barra, Arturo Z. Vásquez-Parraga and Antonio Farías, (2013). The Effects of Service Quality on Customer Trust and Satisfaction in Internet Banking. ESTUDIOS DE ADMINISTRACIÓN, VOL. 20, Nº 1 (2013), PP. 1-3

[12]. Fombrun, C.J., Gardberg, N.A. , and Sever, J.M.(2000). The reputation quotient: a multiple stakeholder measure of corporate reputation. Journal of Br, and Management, 7(4), 241-255.

[13]. Girish Nair, PhD (2016), Impact of Service Quality on Business Performance in Hospitality Industries: An empirical study. Journal of Tourism, Hospitality and Sports www.iiste.org. ISSN (Paper) 2312-5187 ISSN
(Online) 2312-5179 An International Peer-reviewed Journal Vol.17, 2016.

[14]. Herbig, Paul, John Milewichz \& Jim Golden., 2004, A Model of Reputation Building \& Destruction, Journal of Business Research, Vol. 31.

[15]. Husda, Nur Elfi. (2017). Customer Value and Customer Satisfaction As Mediation Of Misand Service Quality To Brand Trust, and Reputation Of Private Universities In Kepulauan Riau Province. International Conferences on Information Technology and Business (ICITB), 7th Dec 2017.

[16]. Igbaria, M., Zinatelli, N., Cragg, P. \& Cavaye, L.M. (1997). "Personal Computing Acceptance Factors in Small Firms: A Structural Equation Model". MIS Quarterly 21(3): 279-302.

[17]. Justus M. Kyengo \& James Kilika (2017)," Strategic Assets, Competitive Capabilities, and Firm Performance: Review of the Literature." Journal of Business and Economic Development. Volume 2, Issue 3, August 2017, Pages: 140-147.

[18]. Liang Li, Bangzhu Zhu, Xiang Cai, Xingle Long, Chanwook Park. (2019). Internal service quality affects salespersons' performance and turnover intention: Mediating role of job involvement. Social Behavior and Personality, Volume 47, Issue 8, e8251 https://doi.org/10.2224/sbp.8251 www.sbpjournal.com

[19]. Majid Esmaeilpour, Amrollah Sayadi, Mahnaz Mirzaei, (2017). Investigating the Impact of Service Quality Dimensions on Reputation and Br, and Trust. International Journal of Business and Economic Sciences Applied Research. International Journal of Business and Economic Sciences Applied Research, Vol. 10, No.3, 7-17.

[20]. Metha Aryska, (2017). "Pengaruh reputasi perusahaan dan kualitas pelayanan terhadap kepuasan pasien (kasus rumah sakit islam ibnu sina pekanbaru)". Jom fisip vol. 4 no. 1 - februari 2017.

[21]. Mcknight, D. H., V. Choudury., \& C. J. Kacmar. (2002). Developing and Validating Trust Measure for E-Commerce: An Integrative Typology. Information System Research. 13(3), hal334-59.

[22]. Mombang Sihite \& Moses Alfian Simanjuntak (2015). "The Competitive Strategy in Green Building for Indonesian Stakeholders". International Journal of Innovation, Management, and Technology, Vol. 6, No. 1, February 2015.

[23]. Nixon Kamukama, Augustine Ahiauzu, \& Joseph M. Ntayi (2011). "Competitive advantage: a mediator of intellectual capital and performance. "Journal of intellectual capital.

[24]. Nham Phong Tuan and Takahashi Yoshi (2010). "Organisational Capabilities, Competitive Advantage and Performance In Supporting Industries In Vietnam."

[25]. Peppers Don and Marta Rogers. (2004). Managing Customer Relationship. Canada: Willey.

[26]. Robinson, Steward. (1999). Measuring Service Quality: Current Thinking and Future Requirements. Marketing Intelligence Planning. Vol. 17, No.1, 2132. 
[27]. Robert L. Hadi, James D.D Massie, Agus S. Soegoto, (2018). Analisis Kualitas Layanan Dan Diferensiasi Jasa Terhadap Kinerja Layanan Hotel Sahid Kawanua Manado.

[28]. Sadia Majeed (2011). "The Impact of Competitive Advantage on Organizational Performance."European Journal of Business and Management'.

[29]. Selness, Fred (1993), A Examination of The Effect of Product Performance on Br, and Reputation, Satisfaction and Loyalty, European Journal of Marketing, Volume 27.

[30]. Simon, Kevin., Christina Whidya Utami \& Metta Padmalia. (2016). Pengaruh Kualitas Layanan Terhadap Kepuasan Pelanggan Surya Nalendra Sejahtera Tours \& Travel. PERFORMA: Jurnal Manajemen dan Start-Up Bisnis Volume 1, Nomor 3, Agustus 2016.

[31]. Tsietsi Mmutle and Last Shonhe, (2017). Customers' perception of Service Quality and its impact on reputation in the Hospitality Industry. African Journal of Hospitality, Tourism and Leisure, Volume 6 (3) (2017) ISSN: 2223-814X

[32]. Torres, Eduardo, Moraga. (2013). The Effects of Service Quality on Customer Trust and Satisfaction in Internet Banking. Estudios de Administración, vol. 20, $\mathrm{N}^{\mathrm{o}}$ 1, 2013, pp. 1-36.

[33]. Vázquez , Luis Enrique Valdez-Juárez , and Ángela María Castuera-Díaz, (2019). Corporate Social Responsibility as an Antecedent of Innovation, Reputation, Performance, and Competitive Success: A Multiple Mediation Analysis. Sustainability 2019, 11(20), 5614; https://doi.org/10.3390/su11205614

[34]. Walsh, Vincent-Wayne Mitchell, Paul R. Jackson and Sharon E. Betty (2008). Examining the antecedents and consequences of corporate reputation: a customer perspective, British Journal of Management. Vol.8:17.

[35]. Wijayanto A, Suhadak, Dzulkirom M. dan Nuzula N.F. (2019). The Effect of Competitive Advantage on Financial Performance and Firm Value: Evidence from Indonesian Manufacturing Companies.

[36]. Wulandari Anna, Rasipan. (2017). Peran Reputasi Dalam Membangun Kepercayaan Konsumen. Jurnal Manajemen dan Kewirausahaan Vol. 14 No. 2 Desember 2017

[37]. Zeithaml, V.A., Parasuraman, A., \& Berry, L.L. (2009). SERVQUAL: a multiple-item scale for measuring consumer perceptions of service quality. Journal of Retailing, 64(1 